\title{
Kaolin And Irrigation Intervals Affect Growth And Essential Oil Of Sweet Basil.
}

\author{
Rania M.R. Khater ${ }^{1}$ and Esam A. A. Al-Azzony ${ }^{2}$
}

${ }^{I}$ Medicinal and Aromatic Plants Department, Desert Research Center, Cairo, Egypt

${ }^{2}$ Medicinal and Aromatic Plants Department, Agriculture Research Center, Cairo, Egypt.

Received: 20 Oct. 2020 / Accepted 10 Dec. 2020 / Publication date: 25 Dec. 2020

\begin{abstract}
The present study was conducted at the experimental at Baluza Research Station, Desert Research Center located at, North Sinai governorates during two consecutive seasons (2018 and 2019). Sweet basil plants were subjected to different irrigation intervals (every 3, 6 and 9 days) and various levels of kaolin $(0,2$ and $4 \mathrm{~cm} 3 / 1)$. The experimental design followed a split plot design. Growth characters and essential oil composition were measured. The results obtained explained, the irrigation intervals affected all the characteristics positively, as all the growth characteristics increased, and the increase was significant and the best treatment was when irrigating at a rate of 3 days. In addition to that, the different concentrations of kaolin resulted in a significant effect on the productivity of basil plants, as the best treatment was when spraying kaolin at a rate of $4 \mathrm{~cm} / 1$. As for the interaction between irrigation intervals and spraying with kaolin, it led to a significant increase in all characters such as plant height $(\mathrm{cm})$, dry weight of leaves ( $\mathrm{g} / \mathrm{plant}$ or ton/ feddan), essential oil $(\%, \mathrm{ml} / \mathrm{plant}$ and liter/feddan), and essential oil constituents ( linalool and estragole) when treatment 6 days + spraying kaolin $4 \mathrm{~cm} / 1$.
\end{abstract}

Keywords: Basil, Ocimum basilicum L., Irrigation intervals, Kaolin, Linalool, Astragol

\section{Introduction}

Sweet basil (Ocimum basilicum, L.) is herb plant that follows the family Lamiaceae and is famous for its many benefits. It is used as a spice and as used in Asian and Italian cuisine because of its distinctive aroma and flavor.

Basil oil contains a large amount of essential aromatic ingredients (such as phenolic compounds) and nutrients magnesium - iron - potassium - calcium and some vitamins (C A K), folic acid and omega-3 acids. Moreover, it contains a group of antioxidants (polyphenols), such as: flavonoids and anthocyanins, and all of these compounds are due to the medicinal effect of basil. Rania 2015 and Gunther, (1961)

Basil helps relieve pain and reduce inflammation and swelling. It also contributes to the treatment of arthritis, rheumatism, the digestive system and intestinal infections. Moreover, basil is refreshing and fragrant for oral odor. On the other hand, basil has an anti-bacterial effect and contains strong antioxidants. Gill, and Randhawa, (1992) and Stary, and Jirasek, (1975)

Irrigation is an important agricultural operation as it is a way to supply plants with water that enables them to grow. Many studies were conducted to find out the importance of irrigation, as Rania, (2010) on Nicotiana glauca plant indicated that, the irrigation at a rate of 4,8,121/plant / week was record the highest yield of active ingredients such as alkaloids, anabasine and rutin contents, " as well as, the highest values of vegetative growth characters such as plant height, number of branches, dry weight per plant and plant content of mineral elements such as N, P , K, Zn, Mn and Fe Also, El-Mekawy, 2006 showed that on Achillea santolina L. plant can be irrigate plants every 14 or 21 days with salinity water $3000 \mathrm{ppm}$ or irrigation every 7 days with salinity water $5000 \mathrm{ppm}$ without any significant decrease in growth, yield and oil production.

Kaolin is an anti-transpiration material that reduces evaporation by making a film on the surfaces of the leaves. Rania , (2010) indicated that, spraying with antitranspirants resulted in a significant increase in vegetative growth such as "plant height, number of branches and fresh and dry weights of the leaves. The results also showed that, an increase in the active ingredients of Nicotiana glauca in both seasons.

On the other hand, Rania, (2015) on Ocimum basilicum L. indicated that, spraying with kaolin 5\% led to a significant increase in vegetative growth and oil production. The results also showed that, an

Corresponding Author: Rania M.R. Khater, Medicinal and Aromatic Plants Department, Desert Research Center, Cairo, Egypt. 
increase in all the growth characters and the main components of essential oil of basil, where the linalool increased to $35.43 \%$, while the estrogenic decreased to $0.75 \%$ compared to the control and other treatments.

The study aims to evaluate the effect of different irrigation intervals and spraying kaolin with different concentrations and the interaction between them to improve the production of leaves and essential oil for basil plant, as well as the main components of essential oil to obtain the best treatment to reduce the water irrigation.

\section{Materials and Methods}

The present study was conducted at the experimental at Baluza Research Station, Desert Research Center located at North Sinai governorates during two consecutive seasons 2018/2019. This experiment included nine treatments which were the combinations between three levels irrigation intervals $(3,6$ and 9 days) and three concentrations of kaolin which were" control (without spraying kaolin), 2 and $4 \mathrm{~cm} 3 / 1$ Plants were irrigated every 3, 6 and 9 days each plant refined 4 liters of well irrigation water per each irrigation. The treatments were applied regularly until the treatments at each season. The foliar of kaolin concentrations more applied as foliar application at 35 and 70 days after sowing.

Nine treatments were arranged in split plot design with three replicate, where irrigation intervals in the main plots, while foliar of kaolin concentrations were randomly arranged in the sub-plots. Obtained data were statistically analyzed, the application technique was statistix, version 9 program (Analytical software, 2008). All plants received normal agriculture practices whenever they needed.

Seeds of Ocimum basilicum L. plants were obtained From Research Centre of Medicinal and Aromatic plants, Dokki, Giza and were sow in seedbeds during the first week of March both seasons, respectively. After 45 days transplanting in soil. The distance between hills $25 \mathrm{~cm}$ and $60 \mathrm{~cm}$ between rows. The mechanical and chemical properties of soil used are shown in Table (1) according to (Page, et al.; 1984) at harvesting stage, The plant were cutting two time at 75 and 150 days after planting in the first and second seasons.

Table 1: Physical and chemical properties of the soil used in this study

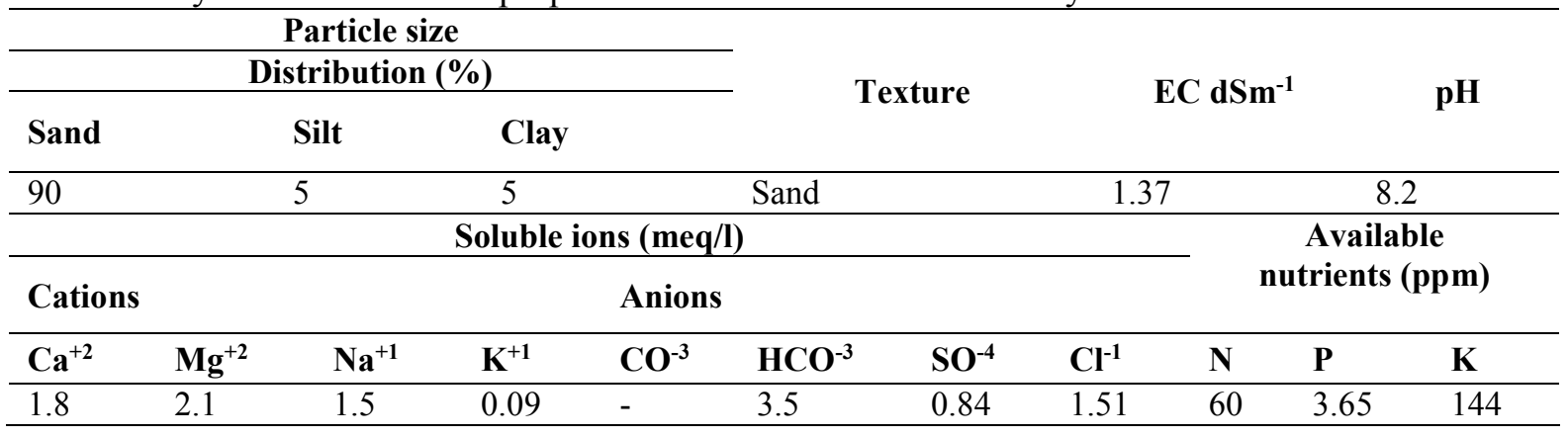

Recorded data plant height $(\mathrm{cm})$, dry weight of leaves $(\mathrm{g} / \mathrm{plant}$ or ton/feddan), essential oil content $\mathrm{ml} /$ plant or liter/feddan, Essential oil constituents were identified by gas liquid chromatography (GLC).

\section{Results and Discussion}

\section{Plant height}

The effects of irrigation intervals (3, 6 and 9 days) were presented in Table (2). There was a significant increase in the plant height the maximum value was recorded at the irrigation intervals 3 days in both seasons which recorded 72.55 and $81.16 \mathrm{~cm}$ compared to the plant height at the irrigation interval 9 days for record 34.15 and $36.10 \mathrm{~cm}$ in the first and second cuts in the first season; respectively. While plant height was recorded at $(70.93$ and $87.08 \mathrm{~cm}),(53.49$ and $65.58 \mathrm{~cm}),(38.48$ and $37.38 \mathrm{~cm})$ in irrigation intervals 3, 6, 9 days in the first and second cuts in the second season, respectively.

These results are in agreement with those obtained by Ouerghi, et al., 2014 on wheat and Patanèa, et al., 2011 on tomato. 
Results in Table (3) observed that, various treatments affected the plant height of the basil plant, as it was a significant increase in both cuts and seasons. The effect of spraying with kaolin, where the highest value was recorded in the plant height at a concentration of $4 \mathrm{~cm} / 1$, which was $55.97 \mathrm{~cm}$, while the plant height $53.50 \mathrm{~cm}$ was recorded at the concentration of $2 \mathrm{~cm} / 1$ compared to the control treatment 51.08 $\mathrm{cm}$ in the first cut of the first season,. As for the second cut, the plant height of recorded $59.96 \mathrm{~cm}$ at the concentration of spraying kaolin $4 \mathrm{~cm} / 1$, while the plant height $2 \mathrm{~cm} / 157.35 \mathrm{~cm}$ compared to the control treatment $54.05 \mathrm{~cm}$ in the first season.

While it was found that there was a significant increase in the second season in both cuts, then it find in the first cut, the plant height was recorded $52.79 \mathrm{~cm}$ when spraying with kaolin $4 \mathrm{~cm} / 1$, while the plant height was recorded at $2 \mathrm{~cm} / 154.15 \mathrm{~cm}$ compared to the control treatment recorded $55.95 \mathrm{~cm}$. As for the second cut, the plant height was recorded $60.76 \mathrm{~cm}$ when spraying with kaolin $4 \mathrm{~cm} / 1$, while the plant height was at $2 \mathrm{~cm} / 163.44 \mathrm{~cm}$ compared to the control treatment which recorded $65.84 \mathrm{~cm}$.

Table 2: Effect of irrigation intervals on growth characters during both seasons

\begin{tabular}{crrrrrrrr}
\hline \multirow{2}{*}{ Treatments } & \multicolumn{4}{c}{ Plant height (cm) } & \multicolumn{3}{c}{ Dry weight of leaves (g/plant) } \\
\cline { 2 - 9 } & \multicolumn{2}{c}{ Season 1 } & \multicolumn{2}{c}{ Season 2 } & \multicolumn{2}{c}{ Season 1 } & \multicolumn{2}{c}{ Season 2 } \\
\cline { 2 - 9 } & Cut 1 & Cut 2 & Cut 1 & Cut 2 & Cut 1 & Cut 2 & Cut 1 & Cut 2 \\
\hline 3 days & $72.55 \mathrm{~A}$ & $81.16 \mathrm{~A}$ & $70.93 \mathrm{~A}$ & $87.08 \mathrm{~A}$ & $51.91 \mathrm{~A}$ & $75.37 \mathrm{~A}$ & $75.03 \mathrm{~A}$ & $81.48 \mathrm{~A}$ \\
6 days & $53.85 \mathrm{~B}$ & $54.10 \mathrm{~B}$ & $53.49 \mathrm{~B}$ & $65.58 \mathrm{~B}$ & $43.26 \mathrm{~B}$ & $49.48 \mathrm{~B}$ & $49.82 \mathrm{~B}$ & $56.09 \mathrm{~B}$ \\
9 days & $34.15 \mathrm{C}$ & $36.10 \mathrm{C}$ & $38.48 \mathrm{C}$ & $37.38 \mathrm{C}$ & $17.06 \mathrm{C}$ & $20.59 \mathrm{C}$ & $22.96 \mathrm{C}$ & $26.65 \mathrm{C}$ \\
\hline
\end{tabular}

These results are in agreement with those obtained by Mohadeseh, et al. (2013) on wheat; Javan, et al., (2013) on soybean and Coniberti, et al., 2013 on berry.

On the other hand, the interaction between the concentrations of kaolin antagonists with the irrigation intervals showed a high significant difference. The results in table 4 , showed that, the plant height increased the highest value 75.40 and $73.53 \mathrm{~cm}$ when spraying with kaolin $4 \mathrm{~cm} / 1$ with the irrigation intervals 6 days compared to the control plants that recorded the plant height 51.85 and 51.74 $\mathrm{cm}$ in the first and second cuts in the first season, respectively. Also recorded the highest value for the plant height in the second season 85.24 and $88.72 \mathrm{~cm}$ at the same treatment compared to the control treatment that recorded 52.15 and $62.51 \mathrm{~cm}$ in the first and second cuts, respectively. These results are in according with those obtained by Coniberti, et al., 2013 on berry; Patanèa, et al., 2011 on tomato and Rania, 2019 on marjoram Gewefile, et al. (2009 a,b) on Nicotiana glauca

This result may be due to several reasons resulting from the effect of kaolin and irrigation on increasing the water content in the plant and thus increasing the absorption of some of the nutrients that improve the photosynthesis process in the leaf and then increasing the growth and it is possible that spraying kaolin led to protect the plant tissue from climatic conditions and increase Efficiency of water that led to the speedy completion of the process of photosynthesis.

\section{Weight of dry leaves (g/plant)}

Regarding to the effect of irrigation intervals on the weight of dry leaves per plant, the irrigation interval exceeded 3 days, followed by 6 days with significant differences when compared with the 9day irrigation intervals in both cuts and seasons. The results were recorded that (51.91 and $75.37 \mathrm{~g}$ ), (43.26 and $49.48 \mathrm{~g}$ ) and (17.06 and $20.59 \mathrm{~g}$ ) in irrigation intervals (3, 6, 9 days / week) in the first and second cuts, respectively, in the first season and were recorded (75.03 and $81.48 \mathrm{~g}),(49.82$ and 56.09 g) and (22.96 and $26.65 \mathrm{~g})$ in the same treatments in the first and second cuts, respectively, in the second season, table (2).

The positive response of Ocimum basilicum L. plants to irrigation intervals was in harmony with those obtained by Ouerghi, et al., 2014 on wheat and Abdel-Fattah, 2013 on Hibiscus rosasinensis L.

Results in Table (3) showed that, a significant increase as a result of the effect of spraying kaolin on the weight of dry leaves per plant (g), where the highest value was recorded at $4 \mathrm{~cm} / 139.04$ and $51.07 \mathrm{~g}$ while when treating plants $2 \mathrm{~cm} / 1$ of kaolin 37.60 and $48.46 \mathrm{~g}$ compared to the control treatment 35.59 and $45.93 \mathrm{~g}$ during in the first and second cuts, respectively, in the first season.

On the other hand, observed that in the second season, the weight of dry leaves per plant (g) was recorded 51.98 and $57.88 \mathrm{~g}$ when spraying with kaolin $4 \mathrm{~cm} / 1$, while the weight of dry leaves per plant 
(g) was recorded at $2 \mathrm{~cm} / 149.19$ and $54.69 \mathrm{~g}$ compared to the control treatment 46.64 and $51.65 \mathrm{~g}$ during the first and second cuts, respectively.

These results are in agreement with those obtained by Bernardo et al. (2017) on grapevine; Conde et al. (2016) on grape berries and El-Khawaga, 2013 on banana plants.

Table 3: Effect of kaolin on growth characters during both seasons

\begin{tabular}{lcccccccc}
\hline \multirow{2}{*}{ Treatments } & \multicolumn{3}{c}{ Plant height (cm) } & \multicolumn{4}{c}{ Dry weight of leaves (g/plant) } \\
& Cut 1 & Cut 2 & Cut 1 & Cut 1 & Cut 2 & Cut 1 & Cut 1 & Cut 2 \\
\hline Controle & $51.08 \mathrm{C}$ & $54.05 \mathrm{C}$ & $52.79 \mathrm{C}$ & $60.76 \mathrm{C}$ & $35.59 \mathrm{C}$ & $45.93 \mathrm{C}$ & $46.64 \mathrm{C}$ & $51.65 \mathrm{C}$ \\
$\mathbf{2} \mathbf{~ c m} / \mathbf{l}$ & $53.50 \mathrm{~B}$ & $57.35 \mathrm{~B}$ & $54.15 \mathrm{~B}$ & $63.44 \mathrm{~B}$ & $37.60 \mathrm{~B}$ & $48.46 \mathrm{~B}$ & $49.19 \mathrm{~B}$ & $54.69 \mathrm{~B}$ \\
$\mathbf{4} \mathbf{~ c m} / \mathbf{l}$ & $55.97 \mathrm{~A}$ & $59.96 \mathrm{~A}$ & $55.95 \mathrm{~A}$ & $65.84 \mathrm{~A}$ & $39.04 \mathrm{~A}$ & $51.07 \mathrm{~A}$ & $51.98 \mathrm{~A}$ & $57.88 \mathrm{~A}$ \\
\hline
\end{tabular}

Data in Table (4) There are significant differences in the weight of dry leaves / plants as a result of the difference of interaction treatments between kaolin concentrations and irrigation intervals where the highest significant difference was recorded in the first season when applying the treatment $4 \mathrm{~cm} / 1+$ 6 days, The weight of dry leaves per plants was recorded at 53.01 and $77.93 \mathrm{~g}$ compared to the control treatment 41.45 and $48.20 \mathrm{~g}$, in the first and second cuts, respectively. While the highest significant difference was recorded in the second season when the same treatment was recorded 77.96 and $85.55 \mathrm{~g}$ compared to the control treatment 47.91 and $52.61 \mathrm{~g}$ in the first and second cuts, respectively.

These results agreed with those reported by Conde, et al., (2016) on grape berries; Ouerghi, et al., (2014) on wheat and Rania, (2010) on Nicotiana glauca; Rania (2019) on Organum majorana

Table 4: Effect of interactions between irrigation intervals and kaolin levels on growth characters during both seasons

\begin{tabular}{|c|c|c|c|c|c|c|c|c|c|}
\hline \multirow{2}{*}{\multicolumn{2}{|c|}{ Treatments }} & \multicolumn{4}{|c|}{ Plant height (cm) } & \multicolumn{4}{|c|}{ Dry weight of leaves (g/plant) } \\
\hline & & Cut 1 & Cut 2 & Cut 1 & Cut 2 & Cut 1 & Cut 2 & Cut 1 & Cut 2 \\
\hline \multirow{3}{*}{$\hat{\overbrace{}}_{n}^{n}$} & Control & $51.85 \mathrm{~F}$ & $52.15 \mathrm{~F}$ & $51.74 \mathrm{~F}$ & $62.51 \mathrm{~F}$ & $41.45 \mathrm{E}$ & $48.20 \mathrm{E}$ & $47.91 \mathrm{~F}$ & $52.61 \mathrm{~F}$ \\
\hline & $2 \mathrm{~cm} / \mathrm{l}$ & $34.18 \mathrm{H}$ & $35.99 \mathrm{H}$ & $38.49 \mathrm{H}$ & $37.64 \mathrm{H}$ & $17.19 \mathrm{G}$ & $20.38 \mathrm{G}$ & $23.09 \mathrm{H}$ & $26.57 \mathrm{H}$ \\
\hline & $4 \mathrm{~cm} / \mathrm{l}$ & $36.58 \mathrm{G}$ & $38.30 \mathrm{G}$ & $38.93 \mathrm{G}$ & $40.24 \mathrm{G}$ & $19.56 \mathrm{~F}$ & $24.16 \mathrm{~F}$ & $25.92 \mathrm{G}$ & $29.70 \mathrm{G}$ \\
\hline \multirow{3}{*}{ 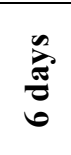 } & Control & $69.70 \mathrm{C}$ & $75.98 \mathrm{C}$ & $68.63 \mathrm{C}$ & $85.52 \mathrm{C}$ & $50.89 \mathrm{C}$ & $72.35 \mathrm{C}$ & $72.14 \mathrm{C}$ & $78.67 \mathrm{C}$ \\
\hline & $2 \mathrm{~cm} / \mathrm{l}$ & $72.56 \mathrm{~B}$ & $82.08 \mathrm{~B}$ & $70.63 \mathrm{~B}$ & $87.01 \mathrm{~B}$ & $51.82 \mathrm{~B}$ & $75.84 \mathrm{~B}$ & $74.10 \mathrm{~B}$ & $81.23 \mathrm{~B}$ \\
\hline & $4 \mathrm{~cm} / \mathrm{l}$ & $75.40 \mathrm{~A}$ & $85.42 \mathrm{~A}$ & $73.53 \mathrm{~A}$ & $88.72 \mathrm{~A}$ & $53.01 \mathrm{~A}$ & $77.93 \mathrm{~A}$ & $77.96 \mathrm{~A}$ & $84.55 \mathrm{~A}$ \\
\hline \multirow{3}{*}{$\begin{array}{l}\hat{D}_{\sigma}^{\circ} \\
\sigma\end{array}$} & Control & $31.68 \mathrm{I}$ & $34.01 \mathrm{I}$ & $38.02 \mathrm{I}$ & $34.25 \mathrm{I}$ & $14.42 \mathrm{H}$ & $17.23 \mathrm{H}$ & $19.88 \mathrm{I}$ & $23.67 \mathrm{I}$ \\
\hline & $2 \mathrm{~cm} / \mathrm{l}$ & $53.76 \mathrm{E}$ & $53.97 \mathrm{E}$ & $53.33 \mathrm{E}$ & $65.68 \mathrm{E}$ & $43.79 \mathrm{D}$ & $49.14 \mathrm{E}$ & $49.47 \mathrm{E}$ & $56.28 \mathrm{E}$ \\
\hline & $4 \mathrm{~cm} / \mathrm{l}$ & $55.92 \mathrm{D}$ & $56.18 \mathrm{D}$ & $55.40 \mathrm{D}$ & $68.56 \mathrm{D}$ & $44.55 \mathrm{D}$ & $51.11 \mathrm{D}$ & $52.07 \mathrm{D}$ & $59.39 \mathrm{D}$ \\
\hline
\end{tabular}

\section{Weigh dry leaves per feddan $\left(4200 \mathrm{~m}^{2}\right)$}

Regarding the effect of irrigation intervals the dry weight of leaves per feddan, the best treatment was the 3 day irrigation intervals followed by 6 day with significant differences when compared to the 9 day in both seasons of the study that recorded (1.453 and 2.111 ton ), (1.212 and 1.386 ton) and ( 0.478 and 0.577 ton ) In irrigation intervals 3, 6, 9 days respectively in the first and second cuts in the first season, respectively and (2.100 and 2.282 ton), (1.393 and 1.572 ton ) and (0.643 and 0.747 ton) in the same treatments in the first and second cuts in the second season, respectively (Table, 5).

Table 5: Effect of irrigation intervals on dry weight of leaves per (ton/ feddan) and essential oil percentage plant during the two seasons.

\begin{tabular}{ccccccccc}
\hline \multirow{2}{*}{ Treatments } & \multicolumn{3}{c}{ Dry weight of leaves (ton/ feddan) } & \multicolumn{4}{c}{ Essential oil percentage } \\
& Cut 1 & Cut 2 & Cut 1 & Cut 2 & Cut 1 & Cut 2 & Cut 1 & Cut 2 \\
\hline 3 days & $1.453 \mathrm{~A}$ & $2.111 \mathrm{~A}$ & $2.100 \mathrm{~A}$ & $2.282 \mathrm{~A}$ & $0.32 \mathrm{~A}$ & $0.32 \mathrm{~A}$ & $0.31 \mathrm{~A}$ & $0.35 \mathrm{~A}$ \\
6 days & $1.212 \mathrm{~B}$ & $1.386 \mathrm{~B}$ & $1.393 \mathrm{~B}$ & $1.572 \mathrm{~B}$ & $0.23 \mathrm{~B}$ & $0.22 \mathrm{~B}$ & $0.22 \mathrm{~B}$ & $0.21 \mathrm{~B}$ \\
9 days & $0.478 \mathrm{C}$ & $0.577 \mathrm{C}$ & $0.643 \mathrm{C}$ & $0.747 \mathrm{C}$ & $0.10 \mathrm{C}$ & $0.10 \mathrm{C}$ & $0.12 \mathrm{C}$ & $0.12 \mathrm{C}$ \\
\hline
\end{tabular}


These results are in agreement with those obtained by Glenn, et al., (2010) on wine grape and Abdel-Fattah, (2013) on Hibiscus rosasinensis L.

Results in Table (6) showed that, a significant increase in the weight of dry leaves per feddan in the first season when spraying with kaolin $4 \mathrm{~cm} / 1$ (1.094 and 1.431 ton), while there was no significant increase when spraying plants with kaolin $2 \mathrm{ml} / 11.053$ and 1.356 ton compared to the control treatment 0.996 and 1.286 ton during the first and second cuts, respectively. On the other hand, the weight of dry leaves per feddan increased in the second season when spraying plants with kaolin $4 \mathrm{~cm} / 1$ followed by $2 \mathrm{~cm} / 1$ and significant differences between them, the significance increased when compared to untreated plants (1.454 and 1.621 ton), (1.377 and 1.532 ton) and (1.306 and 1.448 ton) at concentrations kaolin $0,2,4 \mathrm{ml} / 1$, respectively, during the first and second cuts, respectively.

These results are in agreement with those obtained by Palliotti, et al., (2013) on Sangiovese grapevines, and (2010) on Vitis vinifera, L.

Table 6: Effect of kaolin concentrations on dry weight of leaves per (ton/ feddan) and essential oil percentage during the two seasons.

\begin{tabular}{ccccccccc}
\hline Treatments & \multicolumn{4}{c}{ Dry weight of leaves per feddan (ton) } & \multicolumn{4}{c}{ Oil percentage } \\
\cline { 2 - 9 } & Cut 1 & Cut 2 & Cut 1 & Cut 1 & Cut 1 & Cut 2 & Cut 1 & Cut 1 \\
\hline $\mathbf{C o n t r o l}$ & $0.996 \mathrm{C}$ & $1.286 \mathrm{C}$ & $1.306 \mathrm{C}$ & $1.448 \mathrm{C}$ & $0.20 \mathrm{C}$ & $0.29 \mathrm{C}$ & $0.20 \mathrm{C}$ & $0.22 \mathrm{C}$ \\
$\mathbf{2} \mathbf{~ c m} / \mathbf{l}$ & $1.053 \mathrm{~B}$ & $1.357 \mathrm{~B}$ & $1.377 \mathrm{~B}$ & $1.532 \mathrm{~B}$ & $0.22 \mathrm{~B}$ & $0.21 \mathrm{~B}$ & $0.22 \mathrm{~B}$ & $0.23 \mathrm{~B}$ \\
$\mathbf{4} \mathbf{~ c m} / \mathbf{l}$ & $1.094 \mathrm{~A}$ & $1.431 \mathrm{~A}$ & $1.454 \mathrm{~A}$ & $1.621 \mathrm{~A}$ & $0.23 \mathrm{~A}$ & $0.22 \mathrm{~A}$ & $0.23 \mathrm{~A}$ & $0.23 \mathrm{~A}$ \\
\hline
\end{tabular}

The results shown in the table (6) indicate that there is a significant increase in the weight of dry leaves per feddan due to the effect of interaction between treatments kaolin concentration and irrigation intervals, as the highest significant difference was recorded in the first season when spraying kaolin 4 $\mathrm{cm} / 1+6$ day. It was higher value of dry leaf weight per feddan 1.483 and 2.183 ton compared to untreated plants 1.160 and 1.347 ton in the first and second cuts, respectively. As for the second season, observed that, the highest significant difference when applying kaolin spray $4 \mathrm{~cm} / 1+6$ days where the weight of the leaves per feddan 2.180 and 2.367 ton was compared to the control treatment 1.340 and 1.477 ton in the first and second parts respectively.

The above mentioned results agreed with those obtained by Palliotti, et al., (2013) on Sangiovese grapevines; Glenn, et al., (2010) on wine grape and Wafaa and Rania (2016) on Ricinus communis var. red Arish; Rania and Wafaa (2017) on Ocimum basilicum plants; Elham and Rania (2015) on Hibiscus sabdariffa L.

\section{Essential oil percentage}

Data in the table (7) noticed that, a significant difference in the oil percentage with the effect of irrigation intervals $(3,6,9$ days / week) $(0.32$ and $0.32 \%),(0.23$ and $0.22 \%)(0.10$ and $0.10 \%)$ in the first and second cuts in the first season, respectively. While recording $(0.31$ and $0.35 \%),(0.22$ and 0.21 $\%)$ and $(0.12$ and $0.12 \%)$ in the first and second cuts in the second season, respectively. Regarding to the effect of the interaction between kaolin concentrations and irrigation intervals in the oil percentage. The positive response of Ocimum basilicum, L. plants to irrigation intervals was in harmony with those obtained by Glenn, et al., (2010) on wine grape and Abdel-Fattah, 2013 on Hibiscus rosasinensis, L.

The results in Table (6) show that, the effect of spraying kaolin $(0,2,4 \mathrm{~cm} / 1)$ of basil plants in both cuts and seasons. There is a significant increase in the oil percentage as a result of spraying kaolin $4 \mathrm{ml} / 10.23$ and $0.22 \% \mathrm{~cm}$, while the oil percentage 0.22 and $0.21 \%$ was recorded at the concentration of $2 \mathrm{~cm} / 1$ compared to the control treatment 0.20 and $0.29 \%$ in the first cut and season.

While in the second season, a significant increase in both the first and second cuts. The oil percentage 0.23 and $0.23 \%$ was recorded when spraying with kaolin $4 \mathrm{~cm} / 1$, while when spraying with a concentration of $2 \mathrm{~cm} / 10.22$ and $0.23 \%$ compared to untreated plants 0.20 and $0.22 \%$ in the first and second cuts respectively. Francisco, et al., 2010 on pepper plants ; Ergun, 2012 on apple fruit ;Khaleghi, et al., 2015 on Olea europaea L and Masoud, 2012 on hamawy apricot trees.

In addition that, there are high significant differences were recorded when spraying with kaolin $4 \mathrm{ml}$. Liters + irrigation intervals 6 days. In the first season, where the highest value of oil percentage 0.34 and $0.33 \%$ was recorded in the first and second cuts, respectively compared to the control 
treatment 0.21 and $0.20 \%$ in both cuts, respectively. While the highest significant difference was in the second season at the same treatment where the oil percentage 0.32 and $0.35 \%$ was recorded in the first and second cuts, compared to the control treatment that reached 0.21 and $0.21 \%$ in both cuts, respectively (Table 7).

These results are in according with those obtained by Masoud, (2012) on hamawy apricot trees; Amal et al. (2017) on Mentha viridis; Rania, (2016) on Cyamopsis tetragonoloba L. and Glenn, et al., (2010) on wine grape

Table 7: Effect of the interactions between irrigation intervals and kaolin rates on dry weight of leaves (ton/ feddan) and essential oil percentage during the two seasons.

\begin{tabular}{|c|c|c|c|c|c|c|c|c|c|}
\hline \multirow{2}{*}{\multicolumn{2}{|c|}{ Treatments }} & \multicolumn{4}{|c|}{ Dry weight of leaves (ton/ feddan) } & \multicolumn{4}{|c|}{ Essential oil percentage } \\
\hline & & Cut 1 & Cut 2 & Cut 1 & Cut 2 & Cut 1 & Cut 2 & Cut 1 & Cut 2 \\
\hline \multirow{3}{*}{$\begin{array}{c}\hat{e}_{\mathrm{c}} \\
\frac{\mathrm{E}}{\mathrm{m}}\end{array}$} & control & $1.160 \mathrm{~F}$ & $1.347 \mathrm{E}$ & $1.340 \mathrm{~F}$ & $1.477 \mathrm{~F}$ & $0.21 \mathrm{~F}$ & $0.20 \mathrm{~F}$ & $0.21 \mathrm{E}$ & $0.21 \mathrm{D}$ \\
\hline & $2 \mathrm{~cm} / \mathrm{l}$ & $0.480 \mathrm{H}$ & $0.570 \mathrm{G}$ & $0.647 \mathrm{H}$ & $0.743 \mathrm{H}$ & $0.10 \mathrm{H}$ & $0.19 \mathrm{H}$ & $0.12 \mathrm{G}$ & $0.12 \mathrm{~F}$ \\
\hline & $4 \mathrm{cn}$ & $0.550 \mathrm{G}$ & $0.677 \mathrm{~F}$ & $0.727 \mathrm{G}$ & $0.833 \mathrm{G}$ & $0.12 \mathrm{G}$ & $0.11 \mathrm{G}$ & $0.13 \mathrm{~F}$ & $0.12 \mathrm{E}$ \\
\hline \multirow{3}{*}{ 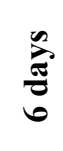 } & contr & $1.423 \mathrm{C}$ & $2.027 \mathrm{C}$ & $2.020 \mathrm{C}$ & $2.203 \mathrm{C}$ & $0.30 \mathrm{C}$ & $0.31 \mathrm{C}$ & $0.30 \mathrm{C}$ & $0.34 \mathrm{~B}$ \\
\hline & $2 \mathrm{~cm} / \mathrm{l}$ & $1.453 \mathrm{~B}$ & $2.123 \mathrm{~B}$ & $2.100 \mathrm{~B}$ & $2.277 \mathrm{~B}$ & $0.32 \mathrm{~B}$ & $0.32 \mathrm{~B}$ & $0.31 \mathrm{~B}$ & $0.35 \mathrm{~A}$ \\
\hline & $4 \mathrm{~cm} / \mathrm{l}$ & $1.483 \mathrm{~A}$ & $2.183 \mathrm{~A}$ & $2.180 \mathrm{~A}$ & $2.367 \mathrm{~A}$ & $0.34 \mathrm{~A}$ & $0.33 \mathrm{~A}$ & $0.32 \mathrm{~A}$ & $0.35 \mathrm{~A}$ \\
\hline \multirow{3}{*}{$\hat{\pi}_{0}^{n}$} & control & $0.403 \mathrm{I}$ & $0.483 \mathrm{H}$ & $0.557 \mathrm{I}$ & $0.663 \mathrm{I}$ & $0.09 \mathrm{I}$ & $0.08 \mathrm{I}$ & $0.10 \mathrm{H}$ & $0.11 \mathrm{G}$ \\
\hline & $2 \mathrm{~cm} / \mathrm{l}$ & $1.227 \mathrm{E}$ & $1.377 \mathrm{E}$ & $1.383 \mathrm{E}$ & $1.577 \mathrm{E}$ & $0.23 \mathrm{E}$ & $0.22 \mathrm{E}$ & $0.22 \mathrm{D}$ & $0.22 \mathrm{C}$ \\
\hline & $4 \mathrm{~cm} / \mathrm{l}$ & $1.250 \mathrm{D}$ & $1.433 \mathrm{D}$ & $1.457 \mathrm{D}$ & $1.663 \mathrm{D}$ & $0.24 \mathrm{D}$ & $0.23 \mathrm{D}$ & $0.22 \mathrm{D}$ & $0.22 \mathrm{C}$ \\
\hline
\end{tabular}

\section{Essential oil content (ml/plant)}

The results in table (8) indicate that, the effect of the 6-day irrigation intervals was significantly greater than (3,9-day). There is a significant increase in oil content per plant in the first and second cuts in the first season, (6) was recorded at the irrigation intervals $(3,6,9$ days / week) $(0.167$ and 0.241 $\mathrm{ml}),(0.098$ and $0.107 \mathrm{ml})$ and $(0.018$ and $0.018 \mathrm{ml})$; respectively, and in the second season, it excelled significantly for oil content per plant $(\mathrm{ml})(0.232$ and $0.280 \mathrm{ml}),(0.108$ and $0.120 \mathrm{ml})$ and $(0.027$ and $0.030 \mathrm{ml}$ ) for the same treatments, respectively.

Table 8: Effect of irrigation intervals on oil content (ml/plant or liter/ feddan) during the two seasons.

\begin{tabular}{lllllllll}
\hline \multirow{2}{*}{ treatments } & \multicolumn{2}{l}{ Essential oil (ml/plant) } & \multicolumn{5}{c}{ Essential oil (liter/ feddanl) } \\
& Cut 1 & Cut 2 & Cut 1 & Cut 2 & Cut 1 & Cut 2 & Cut 1 & Cut 2 \\
\hline 3 days & $0.167 \mathrm{~A}$ & $0.241 \mathrm{~A}$ & $0.232 \mathrm{~A}$ & $0.280 \mathrm{~A}$ & $4.651 \mathrm{~A}$ & $6.753 \mathrm{~A}$ & $6.518 \mathrm{~A}$ & $7.877 \mathrm{~A}$ \\
6 days & $0.098 \mathrm{~B}$ & $0.107 \mathrm{~B}$ & $0.108 \mathrm{~B}$ & $0.120 \mathrm{~B}$ & $2.757 \mathrm{~B}$ & $2.973 \mathrm{~B}$ & $3.041 \mathrm{~B}$ & $3.356 \mathrm{~B}$ \\
9 days & $0.018 \mathrm{C}$ & $0.018 \mathrm{C}$ & $0.027 \mathrm{C}$ & $0.030 \mathrm{C}$ & $0.481 \mathrm{C}$ & $0.546 \mathrm{C}$ & $0.760 \mathrm{C}$ & $0.857 \mathrm{C}$ \\
\hline
\end{tabular}

These results are in agreement with those obtained by Bafeel, and Moftah (2008) on eggplants and Al-Absi, and Archbold, 2016 on Apple tree.

Regarding to oil content (ml/plant) there is an effect of kaolin treatment table (9) and this effect was significant in both cuts and seasons. The best treatment when spraying plants with kaolin $4 \mathrm{~cm} / \mathrm{l}$, followed by $2 \mathrm{~cm} / 1$ and finally the control treatment as recorded $(0.103$ and $0.131 \mathrm{ml}),(0.096$ and 0.123 $\mathrm{ml})$ and $(0.083$ and $0.111 \mathrm{ml})$ The first and second cuts in the first season, and $(0.132$ and $0.153 \mathrm{ml})$, $(0.122$ and $0.144 \mathrm{ml})$ and 0.112 and $0.132 \mathrm{ml})$ in the second season for kaolin concentrations $(0,2,4)$ $\mathrm{cm} / 1$, respectively.

These results are in agreement with those obtained by Savic, et al.,(2011); Lukic, et al., 2012 ); Boari, et al. 2014 and Srinivasa, 2010 on tomato.

Data in Table (9) showed that, a significant increase due to the effect of interaction between kaolin concentrations and irrigation intervals. The highest significant differences in the first season when spraying kaolin $4 \mathrm{ml}$. Liters + irrigation intervals 6 days, as the oil content per plant (ml) 0.180 and $0.253 \mathrm{ml}$ increased compared to untreated plants 0.087 and $0.097 \mathrm{ml}$ in both cuts, respectively. While there was the same effect when the same treatment was spraying kaolin $4 \mathrm{ml}$ per liter + irrigation 
intervals 6 days where the highest significant difference was found in the second season as oil content per plant (ml) 0.250 and $0.293 \mathrm{ml}$ compared to the control treatment 0.100 and $0.107 \mathrm{ml} \mathrm{In}$ both cuts, respectively.

These results agreed with those reported by Srinivasa, 2010 on tomato; Rania, (2015) on Ocimum basilicum L. plant; Rania and Abd El-Azim (2017) on lemon grass and (2016); on Plantago psyllium L. and Moftah (2008) on eggplants.

Table 9: Effect of kaolin on essential oil contents ( $\mathrm{ml} / \mathrm{plant}$ or liter/ feddan) during the two seasons.

\begin{tabular}{ccccccccc}
\hline \multirow{2}{*}{ Treatments } & \multicolumn{3}{c}{ Essential oil (ml/plant) } & \multicolumn{3}{c}{ Essential oil } & (liter/ feddan) \\
\cline { 2 - 9 } & Cut 1 & Cut 2 & Cut 1 & Cut 2 & Cut 1 & Cut 2 & Cut 1 & Cut 2 \\
\hline Control & $0.083 \mathrm{C}$ & $0.111 \mathrm{C}$ & $0.112 \mathrm{C}$ & $0.132 \mathrm{C}$ & $2.372 \mathrm{C}$ & $3.133 \mathrm{C}$ & $3.144 \mathrm{C}$ & $3.718 \mathrm{C}$ \\
$\mathbf{2} \mathbf{~ c m} / \mathbf{l}$ & $0.096 \mathrm{~B}$ & $0.123 \mathrm{~B}$ & $0.122 \mathrm{~B}$ & $0.144 \mathrm{~B}$ & $2.648 \mathrm{~B}$ & $3.429 \mathrm{~B}$ & $3.439 \mathrm{~B}$ & $4.043 \mathrm{~B}$ \\
$\mathbf{4 ~ c m} / \mathbf{l}$ & $0.103 \mathrm{~A}$ & $0.131 \mathrm{~A}$ & $0.132 \mathrm{~A}$ & $0.153 \mathrm{~A}$ & $2.869 \mathrm{~A}$ & $3.710 \mathrm{~A}$ & $3.736 \mathrm{~A}$ & $4.328 \mathrm{~A}$ \\
\hline
\end{tabular}

\section{Essential Oil content (liter/feddanl)}

Data in table (10) showed that, 3 day irrigation intervals gave a significant increase in oil content per feddan (1) in the first season 4.651 and 6.7531 and then gradually decreased at the 9 day irrigation intervals 0.481 and 0.5461 , while the effect of the 6 day was with significant differences, where oil content per feddan (1) 2.757 and 2.9731 in the first and second cuts, respectively. In addition, there is a significant increase in oil content per feddan (1) in the second season irrigation intervals of ( 6.518 and $7.8771),(3.041$ and 3.3561$)$ and (3.041 and 3.3561$)$ for the first and second cuts, respectively for irrigation intervals $(3,6,9$ days / week), respectively.

The positive response of Ocimum basilicum L. plants to irrigation intervals was in harmony with those obtained by Ouerghi, et al., (2014) on wheat and Abdel-Fattah, (2013) on Hibiscus rosasinensis L.

Results in Table (10) show that, a significant increase in oil content per feddan (1) due to the effect of kaolin spray $4 \mathrm{~cm} / 1$ in the first season where oil content per feddan (1) recorded the highest value 4.990 and $7.133 \mathrm{~L}$ while values decreased when spraying plants at a concentration of $2 \mathrm{ml}$. Liters 4.650 and $6.810 \mathrm{~L}$ compared to untreated plants 2.457 and $2.700 \mathrm{~L}$ in the first and second cuts, respectively. On the other hand, the two concentrations of $2,4 \mathrm{~cm} / 1$ were given a significant increase $\mathrm{cm} / 1 \mathrm{in}$ oil content per feddan (1) (6.510 and $7.887 \mathrm{~L}$ ) and ( 6.983 and $8.303 \mathrm{~L}$ ) compared to the control treatment 2.817 and $3.020 \mathrm{~L}$ in the first and second cuts, respectively in the second season of the basil plant.

Table 10: Effect of interaction between irrigation intervals and kaolin concentrations on essential oil contents (ml/plant or liter/ feddan) during the two seasons.

\begin{tabular}{|c|c|c|c|c|c|c|c|c|c|}
\hline \multirow{2}{*}{\multicolumn{2}{|c|}{ treatments }} & \multicolumn{4}{|c|}{ Essential oil (ml/plant) } & \multicolumn{4}{|c|}{ Essential oil (liter/ feddan) } \\
\hline & & Cut 1 & Cut 2 & Cut 1 & Cut 2 & Cut 1 & Cut 2 & Cut 1 & Cut 2 \\
\hline \multirow{3}{*}{ 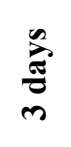 } & Control & $0.087 \mathrm{~F}$ & $0.097 \mathrm{~F}$ & $0.100 \mathrm{E}$ & $0.107 \mathrm{E}$ & $2.457 \mathrm{~F}$ & $2.700 \mathrm{~F}$ & $2.817 \mathrm{~F}$ & $3.020 \mathrm{~F}$ \\
\hline & $2 \mathrm{~cm} / \mathrm{l}$ & $0.020 \mathrm{G}$ & $0.020 \mathrm{G}$ & $0.027 \mathrm{FG}$ & $0.030 \mathrm{FG}$ & $0.473 \mathrm{H}$ & $0.537 \mathrm{H}$ & $0.757 \mathrm{H}$ & $0.853 \mathrm{H}$ \\
\hline & $4 \mathrm{~cm} / \mathrm{l}$ & $0.023 \mathrm{G}$ & $0.023 \mathrm{G}$ & $0.033 \mathrm{~F}$ & $0.037 \mathrm{~F}$ & $0.623 \mathrm{G}$ & $0.717 \mathrm{G}$ & $0.967 \mathrm{G}$ & $1.023 \mathrm{G}$ \\
\hline \multirow{3}{*}{$\hat{e}_{\tilde{b}}^{0}$} & Control & $0.153 \mathrm{C}$ & $0.227 \mathrm{C}$ & $0.217 \mathrm{C}$ & $0.267 \mathrm{C}$ & $4.313 \mathrm{C}$ & $6.317 \mathrm{C}$ & $6.060 \mathrm{C}$ & $7.440 \mathrm{C}$ \\
\hline & $2 \mathrm{~cm} / \mathrm{l}$ & $0.167 \mathrm{~B}$ & $0.243 \mathrm{~B}$ & $0.230 \mathrm{~B}$ & $0.280 \mathrm{~B}$ & $4.650 \mathrm{~B}$ & $6.810 \mathrm{~B}$ & $6.510 \mathrm{~B}$ & $7.887 \mathrm{~B}$ \\
\hline & $4 \mathrm{~cm} / 1$ & $0.180 \mathrm{~A}$ & $0.253 \mathrm{~A}$ & $0.250 \mathrm{~A}$ & $0.293 \mathrm{~A}$ & $4.990 \mathrm{~A}$ & $7.133 \mathrm{~A}$ & $6.983 \mathrm{~A}$ & $8.303 \mathrm{~A}$ \\
\hline \multirow{3}{*}{$\sum_{a}^{\infty}$} & Control & $0.010 \mathrm{H}$ & $0.010 \mathrm{H}$ & $0.020 \mathrm{G}$ & $0.023 \mathrm{G}$ & $0.347 \mathrm{I}$ & $0.383 \mathrm{I}$ & $0.557 \mathrm{I}$ & $0.693 \mathrm{I}$ \\
\hline & $2 \mathrm{~cm} / \mathrm{l}$ & $0.100 \mathrm{E}$ & $0.107 \mathrm{E}$ & $0.110 \mathrm{D}$ & $0.123 \mathrm{D}$ & $2.820 \mathrm{E}$ & $2.940 \mathrm{E}$ & $3.050 \mathrm{E}$ & $3.390 \mathrm{E}$ \\
\hline & $4 \mathrm{~cm} / \mathrm{l}$ & $0.107 \mathrm{D}$ & $0.117 \mathrm{D}$ & $0.113 \mathrm{D}$ & $0.130 \mathrm{D}$ & $2.993 \mathrm{D}$ & $3.280 \mathrm{D}$ & $3.257 \mathrm{D}$ & $3.657 \mathrm{D}$ \\
\hline
\end{tabular}

These results are in agreement with Those obtained by Shellie, and King, $(2013 \mathrm{a}, \mathrm{b})$ on red wine grape; Ahmed (2019) on Solanum lycopersicum L and Song, et al., (2011) on rose .

In general, Table (10) show a significant increase in Oil content per feddan (1) in the plant due to the effect of spraying kaolin and the irrigation intervals in both cuts and seasons. 
The results shown in the table (10) indicate that, a significant increase in Oil content per feddan (1) by the effect of interaction between kaolin concentration and irrigation intervals, as the highest significant difference in the first season when spraying with $4 \mathrm{ml} / 1$ kaolin plus 6 days irrigation intervals, which The oil content per feddan (1) it recorded 4.990 and $7.133 \mathrm{~L}$ compared to the control plants which recorded 2.457 and $2.700 \mathrm{~L}$ in the first and second cuts, respectively. In the second season, the highest significant difference in oil content per feddan (1) when spraying with kaolin concentration $4 \mathrm{~cm} / 1$, and the irrigation intervals 6 days, which recorded 6.983 and $8.303 \mathrm{~L}$ compared to untreated plants that reached 2.817 and 3.020 in the first and second cuts, respectively.

The above mentioned results agreed with those obtained by Ahmed (2019) on Solanum lycopersicum L; El Laban, et al. (2017) on dutch fennel; Abd El-Azim, et al. (2017 and 2016) on Foeniculum vulgare, Mill. and Abdel-Fattah, (2013) on Hibiscus rosasinensis L.

The reason for the increase in Oil content per feddan (l) is due to the spraying of kaolin with the regulation of irrigation leading to the availability of nutrients in the soil with easy absorption and access to the plant. Also, the kaolin spray led to closing the stomata, which led to a decrease in transpiration that worked to keep the leaves with water and thus an increase in photosynthesis and biological processes. This reflected positively in the yield of the basil plant, so the branches increased on the plant and thus an increase in the yield of leaves and the contents of the leaves from the oil per plant and feddan.

\section{Essential oil constituents}

Results of the chromatographic analysis of oil samples extracted from (Ocimum basilicum) plants in the first season (Table 11) show that Linalool was the most important essential oil component (with contents of 30.548 to $46.779 \%$ ), followed by $\beta$ - Caryophyllene (with contents of 6.215 to $18.277 \%$ ), then 1,8 Cineol (with contents of 0.146 to $11.659 \%$ ).

The data presented in Table (11) show the effect of irrigation intervals treatments on Linalool content in the oil extracted from Ocimum basilicum plants. The highest mean content $(46.779 \%)$ was recorded in the oil of plants grown at the irrigation intervals $(6$ days $+4 \mathrm{~cm} / 1)$, followed plants grown at irrigation intervals of 3 days (which gave a mean Linalool content of $46.075 \%$ ), whereas the lowest content $(30.548 \%$ ) was obtained from plants grown at the irrigation intervals ( 9 days only).

On the other hand, estragole, an unwanted compound in the essential oil of basil, was given a lower value when using 6 days with $4 \mathrm{~cm} /$ liter kaolin $0.876 \%$

Table 11: Effect of irrigation intervals and kaolin concentrations on the essential oil components (\%).

\begin{tabular}{|c|c|c|c|c|}
\hline Treatments & 1,8 Cineol & Linalool & Estragole & $\beta$-Caryophyllene \\
\hline 3 days & 0.756 & 46.075 & 0.328 & 0.471 \\
\hline 3 days $+2 \mathrm{~cm} / \mathrm{l}$ & 0.204 & 39.796 & 2.241 & 5.863 \\
\hline 3 days $+4 \mathrm{~cm} / \mathrm{l}$ & 0.342 & 42.770 & 5.674 & 3.766 \\
\hline 6 days & 9.092 & 42.612 & 2.242 & 6.252 \\
\hline 6 days $+2 \mathrm{~cm} / \mathrm{l}$ & 10.236 & 35.861 & 1.472 & 17.557 \\
\hline 6 days $+4 \mathrm{~cm} / \mathrm{l}$ & 11.659 & 46.779 & 0.876 & 18.277 \\
\hline 9 days & 0.146 & 30.548 & 1.249 & 6.215 \\
\hline 9 days $+2 \mathrm{~cm} / \mathrm{l}$ & 4.535 & 45.225 & 1.681 & 14.201 \\
\hline 9 days $+4 \mathrm{~cm} / \mathrm{l}$ & 8.770 & 42.720 & 2.278 & 18.553 \\
\hline
\end{tabular}

\section{Reference}

Abd El-Azim, W.M., M.Y.M. Badawy, and Rania M. Khater, 2016. Effect of mycorrhiza and phosphate dissolving bacteria and licorice extract on growth and oil productivity of Foeniculum vulgare, Mill. plant under Baluza in North Sinai conditions. Middle East Journal of Applied Sciences 6 (4): 990-1002.

Abd El-Azim, W.M., Rania M. Khater and M.Y.M. Badawy, 2017. Effect of bio-fertilization and different licorice extracts on growth and productivity of Foeniculum vulgare, Mill. Plant. Middle East J. of Agriculture Research, 6 (1): 1-12. 
Abdel-Fattah, G.H., 2013. Response of water stressed rose of China (Hibiscus rosasinensis L.) plant to treatment with calcium carbonate and vapor gard antitrans pirants. J. Appl. Sci. Res., 9 (6): 35663572 .

Ahmed, A., 2019 Impacts of Kaolin and Pinoline foliar application on growth, yield and water use efficiency of tomato (Solanum lycopersicum L.) grown under water deficit: A comparative study. Journal of the Saudi Society of Agricultural Sciences. 8 (3): 256-268.

Al-Absi, K.M., and D.D. Archbold, 2016. Apple tree responses to deficit irrigation combined with periodic applications of particle film or abscisic acid. Horticulturae 2(4): 16, doi:10.3390/horticulturae2040016.

Amal, M. Omar, Rania M. Khater and M.I. Sherif, 2017. Using rhizobacteria and some growth promoting substances for improving of Mentha viridis productivity and its antioxidants. Egypt. J. of Appl. Sci., 32 (1): 17-40.

Bafeel, S.O., and A.E. Moftah, 2008. Physiological response of eggplants grown under different irrigation regimes to antitransplant treatments. Saudi J. Biol. Sci., 15(2):259-267.

Bernardo, S., L.-T. Dinis, A. Luzio, G. Pinto, L.V. MónicaMeijón, A. Conde, H. Gerós, C.M. Correia, and J. Moutinho-Pereira, 2017 Kaolin particle film application lowers oxidative damagemand DNA methylation on grapevine (Vitisvinifera L.). Environ Exp Bot. https://doi.org/10.1016/j.envexpbot.2017.04.002

Boari, F., G. Cucci, A. Donadio, M.I. Schiattone, and V. Cantore, 2014. Kaolin influences tomato response to salinity: physiological aspects. Acta Agric. Scand., Sect. B: Plant Soil Sci. http://dx.doi.org/10.1080/09064710.2014.930509.

Conde, A., D. Pimentel, A. Neves, L.-T. Dinis, S. Bernardo, C.M. Correia, H. Gerós, and J. MoutinhoPereira, 2016. Kaolin foliar application has a stimulatory effect on phenylpropanoid and flavonoid pathways in grape berries. Front Plant Sci. 7:1150

Coniberti, A., V. Ferrari, E. Dellacassa, E. Boido, F. Carrau, and V. Gepp, 2013 Kaolin over sunexposed fruit affects berry temperature, must composition and wine sensory attributes of sauvignon blanc. Eur. J. Agron., 50:75-81.

Coniberti, A., V. Ferrari, E. Dellacassa, E. Boido, F. Carrau, V. Gepp, et al., 2013. Kaolin over sunexposed fruit affects berry temperature, must composition and wine sensory attributes of Sauvignon blanc. Eur. J. Agron. 50: 75-81. http://dx. doi.org/10.1016/j.eja.2013.06.001.

El Laban, H.M., Fetouh, M.I. Rania, M.R. Khater and S.H. El-Gioushy, 2017. Response of Dutch Fennel to Algae Extract Partial Replacement of Mineral NPK under Sinai Conditions. J. Plant Production, Mansoura Univ., 8(6):693 - 698.

El -Laban, H.M., Fetouh, M.I. Rania, M.R. Kather and S.M. El-guoshy, 2020. Effect of plant density on vegetative growth, fruits yield, essential oil and chemical constituents of Dutch Fennel under Sinai conditions. ES. J. Agri. Curr. Res. 1(1): 1001.

Elham M. Attia and Rania M. Khater, 2015. Effect of different planting dates and organic fertilizers treatments on growth and yield of Hibiscus sabdariffa L. plants. Egyptian J. Desert Res., 65(1): 153-170.

El-Khawaga, A.S., 2013. Response of Grand Naine banana plants grown under different soil moisture levels to antitranspirants application. Asian J. Crop Sci. 5 (3) : 238-250.

Ergun, M., 2012. Postharvest quality of 'galaxy' apple fruit in response to kaolinbased particle film application. J. Agric. Sci. Technol. 14: 599-607.

Francisco, M.D., C. Paula, J. David, M. Walker, J. Cámara, and R. Madrid, 2010. Effect of foliar application of antitranspirant on photosynthesis and water relations of pepper plants under different levels of CO2 and water stress. J. Plant Phys. 15 (167): 1232-1238.

Gewefile, S.G.M., G.A.A. Bishr, Kamelia M. Reda and Rania M. Khater, 2009b. Effect of different saline water irrigation and compost levels on the growth and active ingredients of Nicotiana glauca under Sinai conditions. J. Agric. Sci. Mansoura Univ., 34(4): 3533-3546.

Gewefile, S.G.M., G.A.A. Bishr, Kamelia M. Reda and Rania M. Khater , 2009a. Effect of irrigation water and antitranspirants on the growth and active ingredients of Nicotiana glauca under Sinai conditions. J. Agric. Sci. Mansoura Univ., 34(4): 3519-3531.

Gill, B.S. and G.S. Randhawa, 1992. Effect of transplanting dates and stage of harvesting on the herb and oil yields of French basil (O. basilicum L.). Indian Perfumer, 36: 102-110. 
Glenn, D.M., N. Cooley, R. Walker, P. Clingeleffer and K. Shellie, 2010. Impact of kaolin particle film and water deficit on wine grape water use efficiency and plant water relations. Hort. Science, 45 (8): 1178-1178.

Gunther, E., 1961. The Essential Oil. 4th ed., D. Van Norstrand Com. Inc., Canada, 3: 399 - 433.

Javan, M., M. Tajbakhsh and B.A. Mandoulakani, 2013. Effect of antitranspirants application on yield and yield components in soybean (Glycine max L.) under limited irrigation. JABS, 7 (1): 70-74

Khaleghi, E., K. Arzani, N. Moallemi, and M. Barzegar, 2015. The efficacy of kaolin particle film on oil quality indices of olive trees (Olea europaea L.) cv 'Zard' grown under warm and semi-arid region of Iran. Food Chem. 166: 35-41.

Lukic, I., R. Stricevic, N. Durovic, and M. Cosic, 2012. Impact of kaolin-based particle film on tomato water use efficiency. In: Proceedings of the Conference BALVOIS, 28 May-2 June. Ohrid (FYROM).

Masoud, A.A.B., 2012. Impact of some antitranspirants on yield and fruit quality of hamawy Apricot trees grown in sandy soils. Res. J. Agric. Biol. Sci. 8(2) : 78-82.

Mohadeseh, N., F. Paknejad and M. Moarefi , 2013. Effect of concentrations and time of kaolin spraying on wheat aphid. J. Biol. Environ. Sci., 7 (21): 163-168.

Ouerghi, F., M. Ben-Hammouda, J.A. Teixeira Da Silva, A. Albouchi, G. Bouzaien, S. Aloui, H. CheikhM'Hamed, and B. Nasraoui, 2014. The effects of Vapor Gard on some physiological traits of durum wheat and barley leaves under water stress. Agric. Conspec. Sci. 79 (4), 261-267.

Palliotti, A., F. Panara, F. Famiani, P., Sabbatini, G.S. Howell, O. Silvestroni, et al., 2013. Postveraison application of antitranspirant di-1-p-menthene to control sugar accumulation in sangiovese grapevines. Am. J. Enol. Vitic. 64: 378-385.

Palliotti, A., S. Poni, J.G. Berrios, and F. Bernizzoni, 2010. Vine performance and grape composition as affected by early-season source limitation induced with antitranspirants in two red Vitis vinifera L. cultivars. Aust. J. Grape Wine Res. 16: 426-433.

Patanèa, C., T. Simona, and S. Orazio, 2011. Effects of deficit irrigation on biomass, yield, water productivity and fruit quality of processing tomato under semi-arid Mediterranean climate conditions. Sci. Hortic. 129: 590-596.

Rania M. Khater, 2015. Effect of hydrogel and antitranspirants treatments on the productivity of sweet basil (Ocimum basilicum L.) plant. Egyptian J. Desert Res., 65 (2): 193-214.

Rania M. Khater, 2016. Effect of sowing dates and foliar spray with extract algae on cluster bean (Cyamopsis tetragonoloba L.) International Journal of Pharm Tech Research, 9 (9):75-84.

Rania M. Khater, 2019. Effect of fertilization and irrigation with magnetic water on the productivity of marjoram plant. The Arab Journal of Agricultural Sciences Volume III - No. (5) p. 1-30. Doi: 10.21608/asajs.2020.67987.

Rania M. Khater, 2019. Effect of Irrigation with Magnetic Water and Nitrogen Fertilizers Source on the Vegetative Growth, Essential Oil Ingredients and Productivity of Organum Majorana . Journal of Architecture and Construction, 2(3) : 27-40. ISSN 2637-5796

Rania M. Khater and W.M. Abd El-Azim, 2016. Effect of fertilization and humic acid treatments on seeds production of Plantago psyllium L. Egyptian J. Desert Res. 66 (1): 95-114.

Rania M. Khater and W.M. Abd El-Azim , 2017. Effect of different nitrogen sources and magnesium foliar spray on growth, yield and chemical constituents of lemon grass under Sinai conditions. Egypt. J. of Appl. Sci., 32 (1): 41-60.

Rania M. Khater and Wafaa H.A. Abd-Allah , 2017. Effect of some trace elements on growth, yield and chemical constituents of Ocimum basilicum plants. Egyptian J. Desert Res., 67 (1): 1-23.

Rania, M.R., Khater, 2010. Effect of some agriculture treatments on the growth and active ingredients of Nicotiana glauca under Sinai conditions. Ph.D. Thesis. Zagazig Univ.

Savic, S., R. Stikic, Z. Jovanovic, B. Vucelic-Radovic, M. Paukovic, and S. Djordjevic, 2011. Deficit irrigation strategies for production of tomato in greenhouse conditions. In: Proceedings of the 46th Croatian and 6th International Symposium on Agriculture. Opatia, Croatia, pp. 567-570.

Shellie, K.C., and B.A. King, 2013a. Kaolin particle film and water deficit influence red wine grape color under high solar radiation in an arid climate. Am. J. Enol. Vitic.64: 214-222.

Shellie, K.C., and B.A. King, 2013b. Kaolin-based foliar reflectant and water deficit influence Malbec leaf and berry temperature, pigments, and photosynthesis. Am. J. Enol. Vitc. 64: 223-230. 
Song, X.W., C. Wang, Q. Zhang, and Y. Li, 2011. Post- harvest physio-chemical responses of cut rose (Rosa hybrida L.) to antitranspirant and vacuum cooling. Philipp. Agric Scientist. 94 (4) : 368 374.

Srinivasa, N.K., 2010. The effects of antitranspirants on stomatal opening, and the Proline and relative water contents in the tomato. J. Hort. Sci. BioTechnol. 61, 369-372.

Stary, F. and V. Jirasek, 1975 Aconcise Guide in Color Herbs. Hamlyn London, New York, Torento.

Wafaa H. Abd-Allah and Rania M. Khater, 2016. Effect of rock phosphate and mycorrhiza on vegetative growth and productivity of Ricinus communis var. red Arish under North Sinai conditions. Middle East Journal of Agriculture Research, 5 (4): 412-421. 